\title{
Organized crime in the fisheries sector threatens a sustainable ocean economy
}

https://doi.org/10.1038/s41586-020-2913-5

Received: 9 December 2019

Accepted: 20 August 2020

Published online: 11 November 2020

Check for updates

\author{
Emma Witbooi ${ }^{1,2 凶},{\text { Kamal-Deen } \mathrm{Ali}^{3}, \text { Mas Achmad Santosa }}^{4}$, Gail Hurley $^{5}$, Yunus Husein ${ }^{4}$, \\ Sarika Maharaj ${ }^{6}$, Ifesinachi Okafor-Yarwood ${ }^{7}$, Inés Arroyo Quiroz ${ }^{8}$ \& Omar Salas ${ }^{9}$
}

The threat of criminal activity in the fisheries sector has concerned the international community for a number of years. In more recent times, the presence of organized crime in fisheries has come to the fore. In 2008, the United Nations General Assembly asked all states to contribute to increasing our understanding the connection between illegal fishing and transnational organized crime at sea. Policy-makers, researchers and members of civil society are increasing their knowledge of the dynamics and destructiveness of the blue shadow economy and the role of organized crime within this economy. Anecdotal, scientific and example-based evidence of the various manifestations of organized crime in fisheries, its widespread adverse impacts on economies, societies and the environment globally and its potential security consequences is now publicly available. Here we present the current state of knowledge on organized crime in the fisheries sector. We show how the many facets of organized crime in this sector, including fraud, drug trafficking and forced labour, hinder progress towards the development of a sustainable ocean economy. With reference to worldwide promising practices, we highlight practical opportunities for action to address the problem. We emphasize the need for a shared understanding of the challenge and for the implementation of intelligence-led, skills-based cooperative law enforcement action at a global level and a community-based approach for targeting organized crime in the supply chain of organized criminal networks at a local level, facilitated by legislative frameworks and increased transparency.
The global community has for a number of years raised concern about the threat of criminality in the fisheries sector. In 2008, the United Nations (UN) General Assembly sounded an alarm about the "possible connection[s] between international organized crime and illegal fishing in certain regions of the world"1. It urged states to research the links between these two phenomena and the evidence thereof, "bearing in mind the distinct legal regimes and remedies under international law applicable to illegal fishing and international organized crime", respectively ${ }^{1}$. In 2019, the UN Security Council further considered transnational organized crime at sea, including crime in fisheries, a threat to international peace and security ${ }^{2}$. In 2011, a comprehensive report that highlights the vulnerability of the global fishing industry to multiple crime types, many of which were organized crimes, and global evidence thereof, was produced. The report recommended a cooperative criminal law enforcement response to the problem, subsequently echoed by the UN Commission for Crime Prevention and Criminal Justice, to prevent transnational organized crime at sea ${ }^{3}$. INTERPOL established a Fisheries Crime Working Group in 2013 as a conduit for joint law enforcement operations that target transnational organized fisheries crime networks. Lessons learned were shared with the global community, including high-level politicians, at annual international symposia, which led to the adoption of a Ministerial Declaration on Transnational Organized Crime in the Global Fishing Industry (Copenhagen Declaration) in 2018. The Declaration, which is currently supported by 28 states, maps a course of global commitment to combat transnational organized fisheries crime to help to foster a sustainable blue economy.

This Perspective is a distillation of the 16th Blue Paper commissioned by the High Level Panel for a Sustainable Ocean Economy, which presents the current state of knowledge on the question of how organized crime in the fisheries sector impedes the realization of a sustainable ocean economy, including an examination of the various crime types that fall under the term 'fisheries crime', and what practical measures can be taken to counter this ${ }^{4}$.

\section{Defining organized crime in the fisheries sector}

The modern fisheries sector is, as with many other economic sectors, globalized, industrialized and integrated into the worldwide financial market; it is therefore similarly exposed to organized crime. Organized

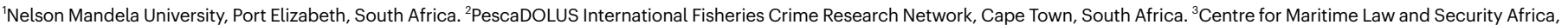

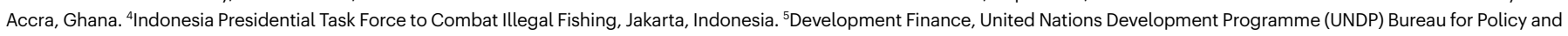

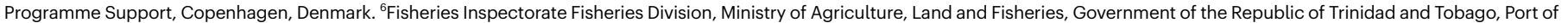
Spain, Trinidad and Tobago. ${ }^{7}$ The Centre for Strategic Research and Studies, National Defence College, Abuja, Nigeria. ${ }^{8}$ Programa de Estudios Socioambientales, Centro Regional de Investigaciones Multidisciplinarias, Universidad Nacional Autónoma de México, Cuernavaca, Mexico. ${ }^{9}$ Security and Government National Planning Department, Agency for Reincorporation and Normalization (ARN) Presidency of Colombia, Bogotá, Colombia. ${ }^{\bowtie}$-mail: emmavdingle@gmail.com 
crime in the fisheries sector is not a new problem; the infamous gangster and businessman $\mathrm{AlCapone}$, for instance, exploited the fishing industry for rum running in the $1920 \mathrm{~s}^{5,6}$. More probably, it is a recent labelling of this phenomenon borne from the current focus on sustainable fisheries management in the context of a sustainable ocean economy that has focused attention on the role of organized crime in the emerging parallel shadow blue economy.

Numerous definitions of organized crime exist ${ }^{7}$. Organized crime is often associated with hierarchical, exclusive and monopolistic groupswith a strong ethnic or societal commonality-that lean towards violence, a criminal subculture or otherwise deviant behaviour ${ }^{8}$. A broader understanding of organized crime, which is used here, is that it consists of networks of individuals that converge and collaborate over time to commit crime, with the profile of those networks varying from loosely knit flat structures to hierarchical chains of command, with correspondingly diverse crime scripts (modus operandi) ${ }^{9}$. Organized criminal groups may share characteristics with 'conventional' businesses, such as their structure and capability ${ }^{10}$, and frequently operate in the 'white-collar' realm ${ }^{11}$. The ability of the network to protect its operations (the 'protection economy')-through violence, bribery or extortion-is a common, but not necessarily defining, feature of organized crime ${ }^{12}$.

From a legal perspective, organized crime is defined in the UN Convention on Transnational Organized Crime (the Palermo Convention) ${ }^{13}$ as a 'serious crime' (an offence "punishable by a minimum deprivation of liberty of at least four years or a more serious penalty") committed by a structured group of three or more people with the aim of obtaining financial or other material benefits.

Although international instruments provide a clear legal benchmark of what constitutes organized crime, outside the letter of the law, both conceptually and in practice, there is often ambiguity around what is regarded as criminal behaviour and, in particular, the extent to which criminal economies associated with organized crime are normalized in any given community ${ }^{14}$.

Crime in the fisheries sector is often referred to as fisheries crime or fisheries-related crime ${ }^{15,16}$. It includes a range of criminal offences throughout the value chain from the preparatory stage to at-sea activities to landing, processing, transportation, trade and sale ${ }^{17}$. Criminal offences may thus be committed at sea, on land, at the coastal interface or in cyberspace, including through the use of the darknet ${ }^{18}$. A commonality is that the offences are profit-driven-that is, they are an economic crime $^{15}$. Many offences are conducted or continued extraterritorially, on the high seas and in other areas beyond national jurisdiction, such as regional seas, making most fisheries crime cases a transnational crime with the added complication of jurisdictional obscurity ${ }^{19}$. Organized crime may take place within the fishing industry or from outside, using the sector as a cover for other criminal activities ${ }^{20}$. In practice many of the same issues pertaining to law enforcement will arise regardless of whether the organized crime is embedded in the industry or not ${ }^{21}$.

Two recent illustrative examples show how organized crime in the fisheries sector may unfold.

\section{The Viking case}

In February 2016, the Indonesian Navy intercepted and detained the fishing vessel Viking in Indonesian waters. The vessel was the subject of an INTERPOL Purple Notice, informing law enforcement agencies globally of the network's use of numerous vessel identities and nationalities (flag states) and the unclear ownership structures of the vessel, making it difficult to identify which country had jurisdiction over the vessel and was responsible for its activities. The owners and operators of the Viking landed and marketed illegally caught Patagonian toothfish from the Southern Ocean for more than a decade in contravention of the multilateral fisheries management regime in the area.

The documents presented on behalf of the vessel were forgeries and the vessel thus sailed under a false identity and flag. As the authorities were unable to trace the vessel's stated owner (suggesting it was a fictional company), the vessel was determined to be stateless and subject to the Indonesian jurisdiction. In Indonesia, document forgery is punishable with imprisonment of up to six years; gillnets were also found in the hold that exceeded $2.5 \mathrm{~km}$ in length, which is a further infringement of the Indonesian law and subject to imprisonment for five years and a criminal penalty of up to US $\$ 150,000$. Investigations revealed three alleged core members of the network's organization: the vessel's master, an Australian national based in Singapore (who acted as the operator of the vessel) and a Spanish national who was domiciled in South Africa (the likely beneficial owner of the vessel). The vessel operated out of ports across Southeast Asia and Africa using forged documents, landing, shipping and trading Patagonian toothfish; they sourced crew, supplies and fuel across the world.

\section{The rock lobster case}

In May 2001, after a tip-off, South African officials seized and opened a container destined for the USA that belonged to the South African company Hout Bay Fishing Industries (Pty) Ltd. The container's contents included unlawfully harvested lobster tails and Patagonian toothfish. The US authorities were alerted and subsequently intercepted the next container exported by the company to the USA. A protracted cooperative investigation followed involving South African and US authorities, culminating in the arrest of the company's main director and two others in 2003 and criminal proceedings in both South Africa and the USA. Investigations revealed that from 1987 to 2001 the network illegally harvested large quantities of west and south coast rock lobster in South African waters for export to the USA, systematically exceeding their authorized quota. The network bribed a large number of government fisheries officers and laundered their profits in a complex web of properties and offshore banks and trusts.

In South Africa, the main director of Hout Bay Fishing Industries was charged with fraud, corruption, bribery, racketeering, violations of the fisheries law and customs offences. In the USA, the directors were found guilty of violating the Lacey Act (which renders it illegal to introduce into the USA any fish or wildlife taken in contravention of the laws of another country) as well as smuggling and conspiracy and were sentenced to imprisonment and forfeiture. A US court initially awarded the South African government around US $\$ 22.5$ million in restitution for damage ${ }^{22}$ (although investigators struggled to locate and freeze the main director's assets to secure the restitution amount) and in September 2018, around 15 years later, a final settlement agreement of US $\$ 7.5$ million was ordered.

The above examples shed light on how the various elements of organized crime may aggregate in a sophisticated criminal operation in a commercial fisheries context and the associated law enforcement challenges. It should be noted that the examples are merely illustrative and are not intended to be representative of how organized crime in fisheries necessarily unfolds, including in the context of vulnerable coastal communities; examples of the latter are discussed below (see 'Drug trafficking').

\section{Organized crime impedes a sustainable ocean economy}

To reach a sustainable ocean economy requires balancing the use of the ocean space and its resources with the long-term carrying capacity of the ocean's ecosystems ${ }^{23}$. In line with the three-pillared concept of sustainable development under the Rio process, a sustainable ocean economy should be based on the sustainable use of the ocean from an economic, social and environmental perspective ${ }^{24}$. Agenda 2030 (adopted at the UN Sustainable Development Summit on 25 September 2015) extends the three dimensions of sustainability to five areas of critical importance (namely, people, prosperity, peace, partnership and 


\section{Perspective}

planet), which should inform synergized interagency policy interventions that will enable the achievement of the Sustainable Development Goals (SDGs).

Organized crime in the fisheries sector has the potential to severely undermine the efforts of the member states to achieve a range of SDGs, including 'zero hunger' (SDG2), 'decent work and economic growth' (SDG8), 'responsible consumption and production' (SDG12) and 'life below water' (SDG14). SDG16 (peace, justice and strong institutions) is a core enabler of the other SDGs ${ }^{25}$, and the targets of SDG16 have particular resonance in the context of addressing manifestations of organized crime in fisheries ${ }^{25}$. This is especially important for vulnerable coastal communities with few alternative livelihood options, which renders them susceptible to recruitment by organized criminal networks.

In the sections below, we introduce the most common serious offences that may comprise manifestations of organized crime in the fisheries sector. Illustrative examples are included to highlight how the effects of these crimes may impede the pursuit of a sustainable ocean economy. The cited examples underscore how the various types of crimes interact and how these crimes, when they converge in the real world-particularly in vulnerable communities-may give rise to a range of complex adverse impacts.

\section{Fraud}

A large amount of documentation is produced along the fisheries value chain, which generates considerable potential for fraud (that is, the deliberate misrepresentation or concealing of facts for undue benefit $)^{17}$. For example, in the Viking case, false vessel registration documents were submitted at port, comprising text that had clearly been cut and pasted from Google translate and using ordinary word-processing software ${ }^{19}$. Fishing vessel identity fraud occurs when a vessel's identity is changed by, for example, not flying the correct flag at port or by physically hiding a vessel's name to render it anonymous ${ }^{19}$. This is associated with 'flag hopping', a pattern of re-registering a vessel with new flag states to confound investigations into its illegal operations, as occurred with the Viking ${ }^{19}$.

Fraudulent practices harm the reputation of both the legitimate fishing industry and the flag state in question. Furthermore, fraudulent fishing licences deprive coastal states of revenue from the legitimate allocation of fishing rights.

On the basis of fraudulent landing certificates, Trinidad and Tobago is cited as the world's sixth largest shark fin exporter to Hong Kong ${ }^{26}$; the fins, in fact, are landed by foreign fishing vessels and merely transit Trinidad and Tobago ports (Republic of Trinidad and Tobago Fisheries Division, personal communication), contributing to the global international illegal trade of shark fins ${ }^{27}$. In 2014, Trinidad and Tobago was also cited by the Convention for the Conservation of Antarctic Marine Living Resources (CCAMLR) as trading in Patagonian toothfish, which is in conflict with the region's fisheries management agreement; however, it was discovered that the trade documents attached to the toothfish exports to Canada that cited Trinidad and Tobago as the port of origin were fraudulent. Fraudulent practices can also give rise to food hygiene risks. At landing, for example, false customs and health documentation can disguise the origin of the catch or the flag of the vessel to avoid paying import tariffs or complying with food hygiene regulations ${ }^{17}$.

In some instances, fish and fish products are fraudulently labelled to avoid paying higher customs duty on high-value species, enabling tax crime $\mathrm{e}^{28,29}$ and thereby depriving coastal states of a further stream of economic revenue.

\section{Tax crime and money laundering}

The fisheries sector lends itself to tax crime given the ease with which criminals can change a vessel's country of origin and identity and use fictitious companies as registered vessel owners; this facilitates channelling profits to shell companies in tax havens to avoid paying tax where the profit was generated ${ }^{19}$. Tax havens (secrecy jurisdictions) are jurisdictions that lack transparency around the beneficial ownership of bank accounts and companies, making it particularly difficult to identify and prove tax crimes.

Tax crime covers a range of violations of tax and revenue rules that are criminalized in law. The loss of tax revenue through tax crimes in fisheries is estimated to be considerable, which severely undermines the development benefits of the sector and particularly adversely affects states in the Global South ${ }^{28}$. In Indonesia, an audit of 187 fishing companies by the Tax Directorate General in 2016 identified potential unpaid tax revenues of around IDR235 billion (more than US\$16 million). The introduction of law enforcement and policy reform in Indonesia against fisheries crime has contributed to a marked increase in tax revenue from the fisheries sector (US $\$ 113$ million in 2018$)^{30}$ (along with an increase in fish stocks ${ }^{31,32}$ ).

Money laundering-the intentional concealing or disguising of the illicit origins of the proceeds of crime $^{13}$-is a type of tax crime and may also be an indication of corruption. Organized criminal networks engage in money laundering in the fisheries sector to integrate the proceeds of crimes committed along the fisheries value chain, or the proceeds from illicit activities outside the sector ${ }^{33}$, into the legitimate economy ${ }^{28}$. Money laundering hampers investigations into organized crime in the fisheries sector and hinders prosecution, including asset recovery, forfeiture of the proceeds of the crime and restitution of illicit gains. In Russia, for instance, the 'crab mafia ${ }^{\text {'34 }}$ has been linked to money laundering (as well as illegal fishing and even assassinations of high-ranking public officials and competitors) ${ }^{35}$. Many offences committed by organized crime groups in fisheries are 'predicate offences' (that is, offences that are a component of a 'primary' crime) to money laundering. In Indonesia, fisheries crime is cited as a predicate offence under the Prevention and Eradication of Money Laundering (Anti Money Laundering) $\mathrm{Law}^{36}$.

\section{Corruption}

Although there is substantial anecdotal evidence of corruption in the fishing industry, and it is suspected to be an enabling factor of many other crimes in the sector, there is limited formal literature, and few decided cases, on the subject ${ }^{15}$. Corruption is the giving, soliciting or receiving of any undue advantage that is aimed at causing an official to act or refrain from acting ${ }^{37}$. This can include, for example, political figures or senior government officials using their positions to influence the allocation of fishing licences to companies in which they have a personal business interest (that is, the abuse of function) ${ }^{17,38,39}$. An illustrative case that is currently under investigation involves an Icelandic fishing company that allegedly used a bank of a neighbouring country and shell companies in the Pacific to channel bribes to obtain fishing licences in Namibia ${ }^{40}$.

Corruption may take the form of bribes paid to reduce penalties ${ }^{41}$, to ignore illegal harvesting of fish ${ }^{15,17}$ or to endorse landing data that are clearly false, as occurred in the rock lobster case. Bribery may extend throughout the criminal supply chain, as in a San Diego case in which it was alleged that a US company brought approximately US $\$ 17$ million worth of sea cucumber from Mexico into the USA by illegally bribing officials along the entire supply chain ${ }^{17,42,43}$.

Corruption in the fisheries sector diverts the revenue that is due to states to the shadow economy and severely undermines advancement towards achieving SDG16, in particular the goal to substantially reduce corruption and bribery.

\section{Drug trafficking}

Fishing vessels are ideal modes of transport for the movement of drugs given their legitimate presence at sea, the lack of transparency around their movement, identity and ownership, and their ability to tranship and access small harbours. The use of fishing vessels to facilitate drug trafficking (the illicit trade of substances that are subject to drug prohibition laws ${ }^{44}$ ) is well documented, as fishing vessels can be used as 
mother ships from which smaller vessels traffic drugs, as support vessels for go-fast boats transiting trafficking routes (for example, in the Caribbean) or as smaller vessels that can traffic drugs directly to and from coastal landing sites and tranship the drugs to mother ships beyond coastal jurisdiction ${ }^{20}$, for example in the Gulf of Guinea ${ }^{41}$.

Fishing vessels may traffic drugs in conjunction with transporting other illicit goods as well as with the smuggling of migrants. In Trinidad and Tobago, for example, artisanal fishing vessels transport drugs and guns from Venezuela to Trinidad and Tobago as well as illegal migrants and, in Jamaica, fishing canoes transport marijuana to Haiti where it is traded for illegal weapons (the 'drugs-for-guns' trade) or cocaine ${ }^{45-47}$. In the Gulf of Guinea, in 2006, a fishing vessel-the MV Benjamin flying a Ghanaian flag-trafficked about 78 parcels $(2,340 \mathrm{~kg})$ of cocaine into Ghana labelled as shrimps ${ }^{48}$.

There is evidence of a close connection between poaching of some high-value species and drug trafficking networks in some parts of the world. In South Africa, for example, poached abalone is bartered with local gangs for the ingredients to manufacture the synthetic drug Mandrax as part of organized criminal networks that illegally export abalone to the East ${ }^{49,50}$. In Mexico, an intricate transnational poaching, drug trafficking and human trafficking network controls the supply chain of illegally harvested Totoaba bladders, which are exported to China ${ }^{51-53}$. In Colombia, organized drug trafficking in the fisheries sector interfaces with a range of inter-related offences including the trafficking of illegal arms, human trafficking, smuggling of fuel and other contraband, large-scale illegal fishing and wildlife trafficking, the response to which requires coordinated operations between the national police, navy and air forces ${ }^{54}$.

The influx of drugs through sea routes, often in conjunction with illicit arms, appears to have a range of negative effects on the coastal communities through which they transit, including a rise in the levels of local violence and associated increased security costs for local businesses (for example, in Trinidad and Tobago ${ }^{55}$ ), weakened social cohesion and sense of security (for example, in the Yucatán Peninsula (Mexico), associated with the illegal sea cucumber fishery) ${ }^{42}$ and increased gang-related activity, for example, in Jamaica ${ }^{47,56-58}$. In South Africa, research indicates that remote coastal communities, such as Buffeljagsbaai, are under siege by organized criminal gangs that illegally harvest abalone on their doorsteps $s^{50,59}$, with women in the woman-lead households becoming accomplices to organized poaching operations with the result that they are subject to criminal prosecution ${ }^{59}$. Given the central role of communities in the supply chain of organized criminal networks, a community-based approach to complement a law enforcement response is arguably valuable and the community, similarly, has a potential preventative role ${ }^{59-62}$.

\section{Crime in the labour market}

Forced labour-that is, work or services exacted from a person under the threat of a penalty and for which the person did not offer himself or herself voluntarily ${ }^{63}$-is increasingly highlighted as pervasive in the fisheries sector globally. It is often a consequence of human trafficking ${ }^{64}$ or 'trafficking in persons' (that is, the procuring of and trading in human beings for the purposes of exploitation $)^{13}$. The problem is documented in a growing body of literature ${ }^{65,66}$ and is increasingly exposed in the media. For example, in 2017, employees of a Scottish family-owned company operating a fleet of scallop dredgers were arrested in southern England after nine individuals who had been trafficked were found on one of their vessels ${ }^{67}$. In the port of Puntarenas, Costa Rica, police rescued 36 Asian individuals who had been subjected to labour exploitation on two fishing boats in 2014, arresting four individuals who were charged with human trafficking offences ${ }^{68}$. In the fishing industry, indicators of forced labour include deception, physical and sexual violence, intimidation, retention of identity documents, withholding of wages, debt bondage and abusive working conditions ${ }^{64}$. Recruitment agencies play a central part in facilitating human trafficking for forced labour $^{66}$. In 2016, a foreign network operating out of north Norway in the Barents Sea crab fisheries was identified as making use of forced labour ${ }^{69,70}$; allegedly a Seychelles recruitment agency, together with Norwegian port agents, facilitated the smuggling of migrant fishers from Indonesia to Norway.

Criminal networks in fisheries use forced labour to cut costs and boost profits ${ }^{71}$. In addition to the implications for human rights, this results in unfair competition with legal operators, which, in turn, can influence legitimate fishing companies to breach domestic crewing regulations in an attempt to remain competitive, such as in the Norwegian snow-crab sector ${ }^{69,70,72}$ and in Russia ${ }^{73}$.

\section{Fisheries offences}

Illegal fishing-fishing in violation of fisheries laws and measures-may also be a criminal offence if it is criminalized under the law of the relevant jurisdiction. Some jurisdictions have severe criminal penalties for fisheries offences, such as Norway, in which grave offences attract a prison sentence of up to six years plus asset forfeiture. Illegal fishing is criminalized in many jurisdictions around the world, including Ghana, Indonesia and South Africa ${ }^{74,75}$. In practice, regardless of whether or not illegal fishing has been criminalized in a jurisdiction, illegal, unreported and unregulated (IUU) fishing is a strong risk indicator of fisheries crime ${ }^{76,77}$.

The adverse effects of large-scale overfishing are well documented ${ }^{78}$. This includes the severe negative impacts on the state of commercially exploitable fish stocks: 2009 data estimated that $18 \%$ of the global catch, valued at US\$10-23.5 billion, between 2000 and 2003 was lost to illegal or unreported fishing ${ }^{79}$. The latest figures of the UN Food and Agriculture Organization (2015 data) estimate that $59.9 \%$ of the world's commercial fish stocks are now fully fished and a third of the global fish stocks are overexploited ${ }^{80}$. As fish stocks decline, the resource becomes more valuable, attracting increasing involvement of transnational organized crime syndicates ${ }^{20}$. Successful prosecution of organized networks can have positive effects on the targeted stocks, as illustrated by the rock lobster case, which resulted in the marked recovery of the targeted species (south coast rock lobster) ${ }^{81}$.

Large-scale illegal fishing can cause severe economic loss to coastal states: the combined annual economic losses due to illegal fishing to Mauritania, Senegal, The Gambia, Guinea Bissau, Guinea and Sierra Leone, for example, are estimated at US $\$ 2.3$ billion $^{48,82}$. A recent global study ${ }^{83}$ estimates that between 7.7 and 14.0 million metric tons of unreported fish catches are potentially traded illicitly each year, suggesting that gross revenues of between US $\$ 8.9$ and US $\$ 17.2$ billion are annually redirected out of the legitimate market through illicit trade. Asia, Africa and South America account for approximately $85 \%$ of total catch losses to likely illicit trade globally. Africa is estimated to experience between US $\$ 7.6$ and US $\$ 13.9$ billion and US $\$ 1.8$ and US $\$ 3.3$ billion in losses annually in economic and income impacts, respectively, owing to the redirection of catches from legitimate to illicit seafood trade $\mathrm{e}^{83}$.

In fishing communities with few alternative livelihood options, low-level poaching may change into, or co-exist alongside, organized criminal activity. In South Africa, this is evident in the context of abalone and west coast rock lobster fishing, where the boundaries between 'protest poaching', opportunistic poaching and facilitation of, or involvement in, organized criminal activity are porous and often overlap ${ }^{59}$. The overexploitation of west coast rock lobster ${ }^{84}$, for example, has led to thousands of subsistence fishers being unable to secure sufficient quotas with the result that some have turned to illegal alternative-income-generating activities ${ }^{85}$.

The UN Special Rapporteur on the Right to Food ${ }^{86}$ has underscored the importance of curtailing illegal fishing to prevent further adverse effects on food security. Fisheries provide an estimated $17 \%$ of animal protein consumed worldwide, with the highest per capita consumption in developing small-island states ${ }^{80}$. In the West African region of the Gulf of Guinea, where around $40 \%$ of the population resides in 


\section{Perspective}

coastal areas, fish is the predominant (and sometimes, only) source of animal protein consumed in coastal communities ${ }^{87}$. In Jamaica, where large-scale overfishing has left most reef fish stocks overexploited ${ }^{88}$, the country is almost entirely dependent on imported fish for domestic consumption.

The marine environment and associated ecosystems may also be negatively affected by organized crime in fisheries: piracy and armed robbery at sea in the Gulf of Guinea pose threats to the marine environment because of the risk of oil or chemical spills caused by the use of destructive weapons to attack vessels and the transfer of the targeted vessel's cargo ${ }^{89}$. In Nigeria, some local fishers struggling to sustain their livelihoods engage in illegal fishing in the vicinity of oil pipeline installations, which risks causing oil leaks and marine pollution $^{90}$. In Mexico, fishers adversely affected by the poorly regulated governmental conservation measures in the Gulf of California have turned to totoaba poaching because of the lack of legitimate alternative livelihoods ${ }^{52}$. The use of gill nets in this illegal activity has brought the vaquita porpoise (caught as bycatch) to the brink of extinction and resulted in severe damage to the large marine ecosystem of the Upper Gulf of California ${ }^{51,91}$. Illegal dynamite ('blast') fishing, associated with explosives trafficking, off the Tanzanian coast is highly destructive to the affected marine habitat, including coral reefs, and fish stocks, and has broad food security ramifications ${ }^{92,93}$.

\section{Smuggling}

The fishing industry provides ideal cover for smuggling of otherwise legal goods from one jurisdiction to another in violation of the law (often to avoid customs duties). In Ecuador, for example, artisanal fishers smuggle subsidized Ecuadorian fuel to the neighbouring coast of Colombia, where it is sold at considerable profit ${ }^{94}$ and Trinidad and Tobago fishing vessels have been implicated in the illegal trade of fuel. Ghana is reportedly at risk of losing about GHS1.5 billion (US $\$ 300 \mathrm{mil}-$ lion) to the smuggling of fuel, which is trafficked by fishing vessels and canoes $^{95}$. Fuel is often smuggled alongside illicit goods, such as drugs, illegal weapons and illegally harvested fish, as well as people ${ }^{94}$.

The use of fishing vessels to smuggle migrants (that is, to facilitate or assist migrants to enter a country illegally for financial or material benefit ${ }^{13}$ ) is alleged to be prevalent, but is less well documented formally. The public media reports that artisanal fishing vessels are the mode of transport to traffic migrant women from South America to Trinidad and Tobago, where some are forced into prostitution and others are transported to the USA ${ }^{96}$. There are also indications that fishing vessels are linked to migrant smuggling in the Mediterranean Sea $^{20,97-99}$, Australia ${ }^{100}$ and Thailand ${ }^{101}$.

\section{Security threats at sea}

Various offences that occur at sea present a threat to peace and security; this can include offences falling within the ambit of organized crime in fisheries. 'Fisheries conflicts' - which may arise from a combination of factors, including illegal fishing (along with climate change and food security concerns)-are recognized as a potential threat to maritime security and livelihoods and there is a growing body of literature on the topic ${ }^{90,102-104}$. In the Gulf of Guinea, numerous organized criminal activities at sea threaten peace and security, including piracy and armed robbery, kidnapping for ransom, fuel and gas robbery and smuggling, drugs and arms trafficking and illegal fishing ${ }^{2}$. This adversely affects the economic bases of the region's states through, for example, increased insurance premiums for cargo vessels, which hinders the movement of goods and services and results in lost income for businesses and governments and an increase in the price of goods and services ${ }^{105,106}$. In Nigeria, for example, piracy and armed robbery at sea is associated with a diminished contribution from the domestic fishing sector to the gross domestic product (GDP) as fewer licensed fee-paying vessels are willing to go to sea ${ }^{90,107}$. Furthermore, coastal fishers who fear putting out to sea in Nigeria due to violent attacks from illegal fishing vessels have been recruited by organized criminal networks engaging in armed robbery at sea and oil smuggling, and fishmongers-who are predominantly women-have in some instances turned to prostitution to make ends meet ${ }^{90,108}$.

A recent Security Council Resolution expressed concern over the links between international terrorism and organized crime, including transnational organized crime at sea ${ }^{109}$. The Security Council has further highlighted the complex relationship between large-scale illegal fishing and the international crime of piracy (as defined in the UN International Law of the Sea $)^{110}$, in Somali waters in the Indian Ocean ${ }^{111-113}$; a similar link has been argued in the case of Southeast Asia ${ }^{114}$.

\section{Challenges and positive practices}

In this section, we highlight particular challenges associated with tackling organized crime in the fisheries sector and, with reference to worldwide promising practices, we present practical opportunities for action to address these challenges.

\section{Challenges}

There are a number of globally identifiable law enforcement challenges concerning the identification, investigation and successful prosecution of organized crime in the fisheries sector. The following challenges are often highlighted in reports and outcome documents from expert group meetings and relevant international gatherings, which draw on operational experience. (1) Low national prioritization of organized crime in fisheries at political and operational levels. "In many countries, crime linked to the fisheries value chain will not be investigated because it is not seen as a major priority and it is difficult to investigate"17. (2) The lack of coordination between government departments and agencies nationally and across borders ${ }^{17,19}$. (3) Inadequate criminal and criminal procedural legislative frameworks ${ }^{17,19}$. (4) The lack of clarity of jurisdiction at sea and extraterritorial jurisdiction: as a result, fisheries crime at sea (beyond national waters) is often not investigated or prosecuted ${ }^{19}$. (5) The lack in capacity and skills of law enforcement agencies and the criminal justice system, particularly around associated financial investigations $s^{15,20,115}$. (6) The lack of transparency in the fisheries sector and financial sector ${ }^{19,20,115}$.

\section{Positive practices}

The complexity of organized crime in fisheries, the potential harm it may cause and the resources needed to combat it all suggest that any strategy should place great emphasis on crime prevention. In this regard, identifying socio-economic drivers of criminal activities is key, including increasing knowledge of demand-driven markets, along with crime-disruption strategies and robust legislative frameworks that criminalize serious offences and attach sufficiently deterrent penalties. As evidence suggests that many criminal networks have already manifested themselves in the fisheries sector, the section that follows thus focuses on enforcement responses, rather than preventative measures. That said, it is worth underscoring that in vulnerable coastal communities, in particular, strengthening the inhabitants' capacity to withstand the intrusion of organized criminal activities is a valuable complement to any law enforcement response ${ }^{59}$. As administrative measures alone are inadequate to deter the illicit operations of criminal networks-the networks absorb such penalties as part of their business models ${ }^{76}-$ it is important to identify effective means to address their activities, underpinned by robust cooperative criminal law enforcement and criminal procedural efforts. In the following sections, we describe some of the promising practices globally in this regard that, subject to critical analyses, could potentially offer ideas for practical ways forward.

Interagency cooperation at national level. Countries use different cooperative interagency enforcement models to address organized crime in fisheries. Indonesia, for example, uses a 'single-roof' enforcement 
agency that brings together five enforcement agencies (the Ministry of Marine Affairs and Fisheries, the navy, the marine police, the coast guard and the Attorney-General's Office) under the Minister of Marine Affairs and Fisheries; Norway's National Advisory Group on Fisheries Crime and IUU Fishing (Fiskeriforvaltningens Analysenettverk) brings together representatives from the coast guard, the police, fisheries, maritime, tax, customs and labour authorities regularly to discuss fisheries cases; and Tanzania's multi-agency task team on environmental and wildlife crime Multi Agency Task Team, led by the Ministry of Home Affairs along with the Ministries of Livestock and Fisheries Development, the Ministry of Energy and Minerals, the Ministry of Natural Resources and the Tanzanian police force, coordinates efforts to target fisheries crime in the region ${ }^{92}$. The Copenhagen Declaration underscores the necessity of effective interagency cooperation; critical research on suitable governance models is therefore important.

Regional and global cooperation. Given the transnational nature of organized crime in the fisheries sector, cross-border cooperation is imperative in investigations, including through the use of mutual legal assistance, INTERPOL tools and judicial requests to cooperate with other countries. The value of such collaboration was highlighted in the Viking case, in which Indonesia invited a multilateral team of experts and INTERPOL to help to facilitate information sharing and analysis. Successful cross-border investigative cooperation also facilitated prosecution in the rock lobster case.

Law reviews and reforms. Many jurisdictions criminalize fisheries offences and have harsh deterrent penalties. For example, the Ghanaian courts may impose a maximum penalty of two years' imprisonment for the illegal exportation of fish under the terms of the 2002 Fisheries Act and in South Africa violations of most provisions of the 1998 Marine Living Resources Act are a criminal offence, attracting a fine of up to ZAR5 million (US\$338,000). Legislation criminalizing other offences that fall under the fisheries crime umbrella is also valuable, such as Indonesian Law 25/2003 on the Crime of Money Laundering, as is organized crime legislation such as South Africa's 1998 Prevention of Organized Crime Act, which criminalizes racketeering and triggers asset forfeiture. The introduction of legislation against human rights abuse on fishing vessels is gaining traction: for example, in February 2019, Thailand ratified the International Labour Organization (ILO) Work in Fishing Convention No. 188 with a view to amend the existing laws in lights of its provisions ${ }^{116}$.

Capacity building and skills training in the criminal justice system. Capacity building can hone enforcement efforts against organized crime in fisheries. Indonesia and Norway, for instance, offer professional accredited training through the International FishFORCE Academy of Indonesia (established in December 2016) and the Norwegian Police University College (since 2010), respectively. The enhancement of skills is particularly valuable to conduct financial investigations that pertain to organized criminal activities in the fisheries sector ${ }^{15}$.

Information exchange and awareness raising. International networks that facilitate information exchange (mindful of data-protection laws and principles) ${ }^{117}$ and intelligence-led law enforcement efforts enhance law enforcement skills to address organized crime in fisheries. International government organizations and international knowledge-sharing symposiums can facilitate this. Legitimate businesses in the fishing industry should also be made aware of organized crime in the sector to encourage corporate social responsibility ${ }^{118}$ practices that improve transparency in the supply chain. Illustrative examples exposed in the media-such as the 2014 revelation in The Guardian that the world's largest Thailand-based prawn farmer was purchasing fishmeal for its prawns from suppliers that were linked to fishing vessels that used individuals who were subjected to human trafficking for forced labour and selling the prawns to the public through top retailers ${ }^{119}$-have heightened public demand for improved transparency of seafood production practices. Civil society can play a part in influencing the substantial content of corporate social responsibility practices and holding companies accountable for their implementation ${ }^{120}$.

\section{Opportunities for action}

With notable exceptions, the world community remains ill-informed that transnational organized crime in fisheries is a distinct problem alongside unsustainable harvesting practices in global fisheries. States are thus largely unaware of the most suitable legal tools to address organized crime in fisheries and, furthermore, that these measures differ from (yet compliment) instruments aimed at improved fisheries management. We suggest that states should first develop a common understanding of organized crime in the global fishing industry at a political level. Thereafter, at an operational level, they should identify and implement suitable technical and practical measures to address the challenges. Mindful of the fact that, globally, states are at various levels of understanding the problem, this should not be interpreted to mean that states should wait for official international consensus of the problem before seeking to address the matter internally. Rather, states with a sufficient grasp of the issue-such as those supporting the Copenhagen Declaration-should be encouraged to proceed to cooperatively implement suitable measures. The suggestions below are formulated as contributions towards the 'solutions-oriented report' of the High Level Panel for a Sustainable Ocean Economy, the content of which is guided by pragmatism, cost effectiveness and political feasibility ${ }^{121}$. To this end, they do not purport to suggest actions aimed at addressing the drivers of organized crime in fisheries; however, effectively addressing organized crime in fisheries will facilitate the achievement of a number of UN SDGs, which, in turn, may contribute to reducing the prevalence of involvement in organized crime in fisheries, particularly among vulnerable coastal communities.

In summary, to address organized crime in the fisheries sector, action in two stages is required. First, a common understanding of transnational organized crime in the fisheries sector at a global level is needed, coupled with the political will to cooperatively address the challenge. Second, political will must be translated into action by states harnessing practical tools to strengthen their law enforcement capacity to effectively tackle organized crime in the fisheries sector.

In more detail, we suggest the following actions should be taken. First, states should be encouraged initially to: (1) report to the UN General Assembly in response to the call made by UN GA Resolution $63 / 112$ to examine connections between illegal fishing and organized crime in fisheries; (2) raise the security implications of transnational organized crime in fisheries at the UN Security Council; (3) formally support the 2018 International Declaration against Transnational Organized Crime (the Copenhagen Declaration); (4) report annually on transnational organized crime in fisheries to the UN Commission for Crime Prevention and Criminal Justice (CCPCJ) and (5) participate in regular international knowledge-sharing forums on organized crime in fisheries.

Second, at a practical level, drawing on the positive practices identified above, armed with a common understanding of the problem, and making use of best-available knowledge, states should be encouraged to strengthen national interagency cooperation, enhance cross-border cooperation and provide for enabling legal frameworks; improve the capacity and skills of criminal law enforcement; strengthen community-based crime prevention, with a focused on gendered implications, which will in turn strengthen the resilience of vulnerable coastal communities and their ability to respond to organized fisheries crime; facilitate civil society engagement with the fishing industry on corporate social responsibility; and support increased publishable research on organized crime in the fisheries sector. 


\section{Perspective}

\section{Outlook}

There is ample anecdotal, scientific and case-based evidence of the many manifestations of organized crime in the fisheries sector and its widespread adverse effects on economies, societies and the environment, including its broader security implications. We show that organized crime in the fisheries sector is widespread in the sense that it is not restricted to specific geographical locations but, rather, that examples are found globally. That said, criminals will tend to seek out the most vulnerable regions of the world in which to conduct their activities, and fisheries crime thus appears to affect most adversely the coastal populations of states with limited resources to prevent and combat it.

There is a noticeable knowledge deficit with regards to the scale of organized crime in the fisheries sector. To date, there is no publicly available statistical data that estimate the extent of organized fisheries crime or that map the incidents and their location at a global level. Existing scientific output and data on criminality in the fisheries sector almost exclusively describe illegal or unreported fishing, which does not take into account the range of criminal offences that occur throughout the fisheries value chain. There is a need to gain further scientific and criminological knowledge of the dynamics and scale of organized fisheries crime and the criminal networks involved therein, including data on the offences in which the criminal networks engage, to identify, evaluate and implement the best measures to address the drivers thereof.

Organized crime in the fisheries sector has the potential to severely undermine the premises for a sustainable ocean economy with notable adverse social, economic and environmental implications. The problem is recognized as sufficiently severe to warrant states' mobilization to take political action. The rate at which support of the Copenhagen Declaration is gaining momentum-particularly among states from the Global South-attests to the fact that states are increasingly acknowledging the existence, extent and adverse impacts of organized fisheries crime. Furthermore, states acknowledge that a failure to effectively address organized fisheries crime will result in a widespread inability to fulfil, among others, the SDG16 goal of 'peace, justice and strong institutions' and, ultimately, will hinder the realization of a sustainable ocean economy. A next important step will be for states that support the Declaration to identify practical measures to operationalize their political commitments on the ground.

1. UN General Assembly. Sustainable fisheries, including through the 1995 Agreement for the Implementation of the Provisions of the United Nations Convention on the Law of the Sea of 10 December 1982 relating to the Conservation and Management of Straddling Fish Stocks and Highly Migratory Fish Stocks, and related instruments. UN Resolution A/RES/ 63/112 https://undocs.org/en/A/RES/63/112 (2008).

2. UN Security Council. Maintenance of International Peace and Security. Transnational Organized Crime at Sea as a Threat to International Peace and Security. 8457th Meeting of the United Nations Security Council Report No. S/PV.8457 (UNSC, 2019).

3. Commission on Crime Prevention and Criminal Justice. Statements of Financial Implications presented to the Commission on Crime Prevention and Criminal Justice before its Consideration of Draft Resolutions at its Twentieth Session. Report No. E/CN.15/2011/21 (UN ODC, 2019).

4. Witbooi, E. et al. Organised Crime in the Fisheries Sector. https://oceanpanel.org/ blue-papers/organised-crime-associated-fisheries (World Resources Institute, 2020).

5. Ensign, E. S. Intelligence in the Rum War at Sea, 1920-1933 (Joint Military Intelligence College, 2001).

6. Demont, J. Maritime Drug Smuggling and Rum-Running. https://www. thecanadianencyclopedia.ca/en/article/maritime-drug-smuggling-and-rum-running (The Canadian Encyclopedia, 17 March 2003).

7. Varese, F. in Redefining Organized Crime: A Challenge for the European Union? (eds Carnevale, S. et al.) 27-56 (Hart Publishing, 2017)

8. Abadinski, H. Organized Crime 8th edn (Thomson Wadsworth, 2007).

9. Madsen, F. Transnational Organized Crime (Routledge, 2009).

10. Australian Crime Commission. Organized Crime in Australia: 2009 (Australian Government, 2009).

11. Gottschalk, P. White-collar Criminals: Cases and Theories of Financial Crime (Unipub, 2012)

12. Shaw, M. \& Kemp, W. Spotting the Spoilers: A Guide to Analyzing Organized Crime in Fragile States (International Peace Institute, 2012).

13. UNODC. United Nations Convention Against Transnational Organized Crime and the Protocols Thereto. https://www.unodc.org/documents/middleeastandnorthafrica/ organised-crime/UNITED NATIONS CONVENTION_AGAINST TRANSNATIONAL ORGANIZED_CRIME_AND_THE_PROTOCOLS_THERETO.pdf (UN , 2004).
This United Nations Convention-which contains the most widely accepted legal definition internationally (through state ratifications) of organized crime and includes a dedicated protocol to combat human trafficking-promotes the use of law enforcement tools, such as mutual legal assistance, to cooperatively combat transnational organized crime globally.

14. Shaw, M. Africa's Changing Place in the Global Criminal Economy. https://globalinitiative. net/wp-content/uploads/2017/09/2017-09-26-enact-continental-report1.pdf (ENACT, 2017).

15. UNODC. Rotten Fish: A Guide on Addressing Corruption in the Fisheries Sector. https:// www.unodc.org/documents/Rotten_Fish.pdf (UN, 2019).

This guide provides an overview of the potential for corruption along the fisheries value chain and provides guidance to authorities in identifying the specific areas in their legal and regulatory frameworks that are susceptible to corruption, and how to address those weaknesses to reduce its impact and develop safeguards to prevent its return.

16. FAO. Draft: Guidance on Social Responsibility in Fisheries and Aquaculture Value Chains (FAO, 2019).

17. UNODC. Stretching the Fishnet: Identifying Opportunities to Address Fisheries Crime. https://bluejustice.org/publication/

stretching-the-fishnet-addressing-crimes-in-the-fisheries-value-chain/ (UN, 2017)

18. Wright, J. Darknet usage in the illegal wildlife trade. Preprint at https://doi.org/10.31235/ osf.io/fgr9d (2019).

There is a growing body of literature on the role of the darknet in the illicit trade of wildlife such as this recent article; there is a paucity of literature that specifically pertains to illicit flows from organized crime in the fisheries sector.

19. North Atlantic Fisheries Intelligence Group. Chasing Red Herring: Flags of Convenience, Secrecy and the Impact on Fisheries Crime Law Enforcement (NA-FIG, 2017). This report draws on case examples to highlight how the lack of transparency around beneficial ownership of fishing vessels and associated corporate financial bodies hinders investigations into organized fisheries crime.

20. UNODC. Transnational Organized Crime in the Fishing Industry: Focus on: Trafficking in Persons Smuggling of Migrants Illicit Drugs Trafficking. https://www.unodc.org/ documents/human-trafficking/Issue_Paper_-_TOC_in_the_Fishing_Industry.pdf (UN, 2011). This comprehensive study highlights the vulnerability of the fishing industry to transnational organized fisheries crime, chronicles examples thereof globally and recommends addressing the problem using a criminal law enforcement approach.

21. Telesetsky, A. Laundering fish in the global undercurrents: illegal, unreported, and unregulated fishing and transnational organized crime. Ecol. Law Q. 41, 939-996 (2015).

22. United States v. Bengis et al. US District Court Southern District of New York S 103 Crim. 0308 (LAK) (2013)

23. Kraemer, R. A. A Sustainable Ocean Economy, Innovation and Growth: A G2O Initiative. CIGI Policy Brief No. 113 https://www.cigionline.org/publications/

sustainable-ocean-economy-innovation-and-growth-g20-initiative (Centre for International Governance Innovation, 2017)

24. UN. The Future We Want: Outcome Document of the United Nations Conference on Sustainable Development. https://sustainabledevelopment.un.org/content/ documents/733FutureWeWant.pdf (UN, 2012).

25. Kercher, J. Fisheries crime and the SDGs: the call and the tools for interagency cooperation. FishCRIME 2018 (UN, 2018).

This presentation outlines the value of locating and addressing organized crime in the fisheries sector in the context of government efforts to achieve the UN SDGs, with particular emphasis on institutional cooperation.

26. The Pew Charitable Trusts Environmental Group. Navigating Global Shark Conservation: Current Measures and Gaps. (Pew, 2012).

27. Clancy, N. Peru Wildlife Agency Eases Export of Illegal Shark Fins. https://www. insightcrime.org/news/brief/peru-wildlife-agency-eases-export-of-illegal-shark-fins/ (InSight Crime, 2019)

This report describes the links between illegal shark fin trade and organized crime.

28. Organization for Economic Cooperation and Development. Evading the Net: Tax Crime in the Fisheries Sector. http://www.oecd.org/ctp/crime/ evading-the-net-tax-crime-fisheries-sector.pdf (OECD, 2013) The extent, nature and implications of tax crime that takes place in the global fishing industry are documented.

29. EUROPOL. Fraud on a Plate: Over 3600 Tonnes of Dangerous Food Removed from Consumer Market. https://www.europol.europa.eu/newsroom/news/fraud-plate-over-3600-tonnes-of-dangerous-food-removed-consumer-market (EUROPOL, 2018).

30. Indonesian Ministry of Finance. Government Revenue Model (Indonesian Ministry of Finance, 2019).

31. Ministry of Maritime and Fisheries Affairs Indonesia. Sea for the Future of the Nation (Ministry of Maritime and Fisheries Affairs Indonesia, 2018).

32. Cabral, R. B. et al. Rapid and lasting gains from solving illegal fishing. Nat. Ecol. Evol. 2, 650-658 (2018).

33. Parks, I. in Following the Proceeds of Environmental Crime: Forests, Fish and Filthy Lucre (ed. Rose, G.) 116-139 (Routledge, 2014).

34. Akhmirova, R. Глава Росрыболовства Андрей Крайний: мы побеждаем мафию! (Head of the Federal Agency for Fishery Andrei Kainy: we are defeating the mafia!) Sobesednik Ru https://sobesednik.ru/politika/20120709-glava-rosrybolovstva-andrei-kr ainii-my-pobezhdaem-mafiyu (2012).

35. Otto, R. S. in King Crabs of the World: Biology and Fisheries Management (ed. Stevens, B. G.) (CRC, 2014).

36. Husein, Y. in Following the Proceeds of Environmental Crime: Forests, Fish and Filthy Lucre (ed. Rose, G.) 71-80 (Routledge, 2014).

37. UN. United Nations Convention Against Corruption. https://www.unodc.org/documents/ brussels/UN_Convention_Against_Corruption.pdf (UN, 2004).

38. Standing, A. Corruption and Commercial Fisheries in Africa. CMI Institute U4 Brief 23 https://www.cmi.no/publications/3189-corruption-and-commercial-fisheries-in-africa (CMI Institute, 2008). 
39. Standing, A. Corruption and State-Corporate Crime in Fisheries. CMI Institute U4 Brief 15 https://www.cmi.no/publications/5589-corruption-and-state-corporate-crime-in-fisheries (CMI Institute, 2015).

40. Wilhjálmsson, I. F. An Icelandic fishing company bribed officials in Namibia and used Norway's largest bank to transfer 70 million dollars to a tax haven. Stundin https:// stundin.is/grein/9920/ (12 November 2019).

41. INTERPOL. Study on Fisheries Crime in the West African Coastal Region (INTERPOL, 2014)

2. Kaplan-Hallam, M., Bennett, N.J. \& Satterfield, T. Catching sea cucumber fever in coasta communities: conceptualizing the impacts of shocks versus trends on social-ecological systems. Glob. Environ. Change 45, 89-98 (2017)

43. US Attorney's Office. Three charged with illegal trafficking of $\$ 17$ million worth of sea cucumbers. https://www.justice.gov/usao-sdca/pr/three-charged-illegal-trafficking 17-million-worth-sea-cucumbers (US Department of Justice, 2017).

44. UNODC. Drug Trafficking. https://www.unodc.org/unodc/en/drug-trafficking/index.html (UN, 2019)

45. Bureau for International Narcotics and Law Enforcement Affairs. 2018 International Narcotics Control Strategy Report Vol. I https://www.state.gov/2018-internationa l-narcotics-control-strategy-report/ (US Department of State, 2018).

46. Neil, J. A. IUU Fishing: A Gateway to Transnational Crimes in Jamaica. MSc thesis, World Maritime Univ. (2018).

47. Witbooi, E. Criminality and Resilience: Rocky Point, Jamaica. Research Report https:// globalinitiative.net/wp-content/uploads/2020/02/Jamaica-report 26.02.v1.pdf (Global Initiative Against Transnational Organized Crime, 2020)

48. Ali, K.-D. Maritime Security Cooperation in the Gulf of Guinea: Prospects and Challenges (Brill/Nijhoff, 2015)

This book provides a comprehensive, in-depth analysis of maritime security prospects and challenges in the Gulf of Guinea.

49. Steinberg, J. The Illicit Abalone Trade in South Africa. ISS Paper No. 105 (Institute for Security Studies, 2005)

50. de Greef, K. \& Raemaekers, S. South Africa's Illicit Abalone Trade: An Updated Overview and Knowledge Gap Analysis. https://www.traffic.org/site/assets/files/8469/ south-africas-illicit-abalone.pdf (Traffic International, 2014). This report provides a synthesis of knowledge about South Africa's illegal abalone fishery, drawing on both available literature and unpublished research spotlighting the history, drivers, impacts and modus operandi of this country's illicit abalone trade.

51. Alvarado Martínez, I. \& Martínez, E. R. in Green Crime in Mexico: A Collection of Case Studies (eds Arroyo Quiroz, I. \& Wyatt, T) 149-170 (Palgrave Macmillan, 2018).

52. Crosta, A., Sutherland, K., Talerico, C., Layolle, I. \& Fantacci, B. Operation Fake Gold. The Totoaba Supply Chain - From Mexico's Totoaba Cartels to China's Totoaba Maw Wholesalers - An Illegal Trade Killing the Vaquita. http://earthleagueinternational.org/ wp-content/uploads/2018/07/EAL-Operation-Fake-Gold-Final.pdf (Elephant Action League, 2018).

53. Miranda, F. Ligan al crimen organizado con extinción de vaquita marina. (Extinction of vaquita marina linked to organized crime.) Milenio https://www.milenio.com/cultura/ ligan-crimen-organizado-extincion-vaquita-marina (1 January 2018).

54. Armada de Colombia. Activación de la Fuerza de Tarea contra el Narcotráfico en el Caribe. (Activation of the Task Force against Drug Trafficking in the Caribbean.) https:// www.armada.mil.co/es/content/ activacion-de-la-fuerza-de-tarea-contra-el-narcotrafico-en-el-caribe (2015).

55. Sutton, H. in The Cost of Crime and Violence: New Evidence and Insights in Latin America and the Caribbean (ed. Jaitman, L.) Ch. 7 (Inter-American Development Bank, 2017).

56. Fisher, H. Rocky Point residents beg for peace. The Jamaica Star (13 April 2016).

57. Robinson, C. It's a 'rocky road': gangsters make life miserable for residents of once-peaceful fishing village. The Jamaica Gleaner (15 January 2017).

58. Leslie, G. Confronting the Don: The Political Economy of Gang Violence in Jamaica (Smal Arms Survey, 2010).

59. Isaacs, M. \& Witbooi, E. Fisheries crime, human rights and small-scale fisheries in South Africa: a case of bigger fish to fry. Mar. Policy 105, 158-168 (2019).

Using empirical research in South Africa, this paper highlights the adverse impacts of organized crime in fisheries on vulnerable coastal communities, with a particular focus on gendered implications, and discusses potentially suitable law enforcement approaches to address the problem.

60. Hübschle, A. \& Shearing, C. Ending Wildlife Trafficking: Local Communities as Change Agents. http://globalinitiative.net/wp-content/uploads/2018/08/ TGIATOC-Wildlife-Trafficking-Report-WEB-4.pdf (Global Initiative Against Transnational Organized Crime, 2018)

61. Cooney, R., Roe, D. Dublin, H. \& Booker, F. Wild Life, Wild Livelihoods: Involving Communities in Sustainable Wildlife Management and Combating Illegal Wildlife Trade (UN Environment Programme, 2018).

62. Hauck, M. \& Sweijd, N. A. A case study of abalone poaching in South Africa and its impact on fisheries management. ICES J. Mar. Sci. 56, 1024-1032 (1999).

63. International Labour Organization. Co29 - Forced Labour Convention, 1930 (No. 29). Article 2 https://www.ilo.org/dyn/normlex/en/f?p=NORMLEXPUB:12100:0::NO::P12100 ILO_CODE:CO29 (ILO, 1930).

64. International Labour Organization. Fishers First: Good Practices to End Labour Exploitation at Sea. https://www.ilo.org/wcmsp5/groups/public/---ed norm/-declaration/documents/publication/wcms_515365.pdf (ILO, 2016) This report by the ILO presents analyses of labour exploitation and includes good practices and interventions to help to eradicating forced labour and other forms of labour exploitation in the global fishing industry.

65. Stringer, C. \& Harre, T. Human trafficking as fisheries crime? An application of the concept to the New Zealand context. Mar. Policy 105, 169-176 (2019).

66. Surtees, R. Trapped at sea. Using the legal and regulatory framework to prevent and combat the trafficking of seafarers and fishers. Groningen J. Int. Law 1, 91-151 (2013) This article provides a comprehensive overview of the chain of illegalities associated with human trafficking for forced labour in the fisheries sector with use of global illustrative examples.
67. Lawrence, F. \& McSweeney, E. UK police rescue nine suspected victims of slavery from British trawlers. The Guardian (December 12 2017).

68. Zueras, D. Costa Rica: (in)human trafficking. IPS News http://www.ipsnews.net/2010/04/ costa-rica-inhuman-trafficking/ (15 April 2010).

69. Thorenfeldt, G. et al. The deadliest catch. Dagbladet https://www.dagbladet.no/arkivert/ magasinet/the-deadliest-catch/70534450 (11 December 2018).

70. Gedde-Dahl, S., Thorenfeldt, G., Stang, L. \& Strømman, O. De skjulte slavekontraktene. (The Hidden Slave Contracts.) Dagbladet https://www.dagbladet.no/nyheter/ de-skjulte-slavekontraktene/70460627 (17 November 2018)

71. Tickler, D. et al. Modern slavery and the race to fish. Nat. Commun. 9, 4643 (2018).

72. Fenstadt A. \& Kvile, K. «Polaris»-reder lover å rydde opp i mannskapsrot («Polaris»-owner promises to clean up mess with crew.) Fiskeribladet https://www fiskeribladet.no/nyhete r/-polaris-reder-lover-a-rydde-opp-i-mannskapsrot/8-1-46419 (14 April 2016.).

73. Krivoshapko, J. Рыба! Антимонопольная служба раскрыла схемы, с помощью которых иностранцы незаконно ловят нашу рыбу (A fish! The antimonopoly service has uncovered schemes by which foreigners illegally catch our fish.) Rossiyskaya Gazeta https://rg.ru/2017/06/20/

fas-raskryla-shemy-po-nezakonnomu-lovu-rossijskoj-ryby-inostrancami.html (20 June 2017)

74. SHERLOC. Database of Legislation. https://sherloc.unodc.org/cld/v3/sherloc/legdb/ (UN ODC, accessed 12 October 2019).

75. FAO Legal Office. Survey of practice on fisheries law enforcement process: administrative $v$ criminal v both. Presentation at Our Ocean 2019 (FAO, 2019)

76. de Coning, E. in Handbook of Transnational Environmental Crime (ed. Elliot, L. \& Schaedla, W. H.) 146-167 (Edward Elgar Publishing, 2016).

This book chapter explores the concept of fisheries crime from a compliance strategy, legal-procedural and socio-legal perspective, drawing out and expanding on the law enforcement implications of fisheries crime.

77. INTERPOL. International Law Enforcement Cooperation in the Fisheries Sector: A Guide for Law Enforcement Practitioners (INTERPOL, 2018).

78. Widjaja, S. et al. Illegal, Unreported and Unregulated Fishing and Associated Drivers. Blue Paper 15 https://oceanpanel.org/sites/default/files/2020-02/HLP\%2OBlue\%2OPaper\%20 on\%2OIUU\%2OFishing\%2Oand\%20Associated\%20Drivers.pdf (World Resources Institute, 2020).

79. Agnew, D. J. et al. Estimating the worldwide extent of illegal fishing. PLoS ONE 4, e4570 (2009).

This paper was one of the first to publically estimate the extent and economic impact of illegal and unreported fishing globally and, in so doing, drew attention to the urgent need to address the problem and the associated enforcement challenges.

80. FAO. The State of World Fisheries and Aquaculture: Meeting the Sustainable Development Goals 2018. http://www.fao.org/3/i9540en/i9540en.pdf (FAO, 2018).

81. Johnston, S. J. \& Butterworth, D. S. Summary of south coast rock lobster (Palinurus gilchristi) fishery. International Fisheries Stock Assessment Review Workshop (Department of Mathematics and Applied Mathematics, Univ. Cape Town, 2017).

82. Doumbouya, A. et al. Assessing the effectiveness of monitoring control and surveillance of illegal fishing: the case of West Africa. Front. Mar. Sci. 7, 50 (2017).

83. Sumaila, U. R. et al. Illicit trade in marine fish catch and its effects on ecosystems and people worldwide. Sci. Adv. 6, eaaz3801 (2020)

84. WWF South Africa v Minister of Agriculture, Forestry and Fisheries and Others (11478/18) [2018] ZAWCHC 127.

85. Cochrane, K. Department will be judged harshly if it fails to protect rock lobster. Cape Times (26 September 2017).

86. UN General Assembly. Fisheries: Interim Report of the Special Rapporteur on the Right to Food. A/67/268 (UN, 2012)

87. Okafor-Yarwood, I. Illegal, unreported and unregulated fishing, and the complexities of the sustainable development goals (SDGs) for countries in the Gulf of Guinea. Mar. Policy 99, 414-422 (2019)

88. The World Bank. Promoting Community-based Climate Resilience in the Fisheries Sector (World Bank, 2017)

89. International Maritime Bureau. Piracy and Armed Robbery against Ships: Report of the Period 1 Jan.-31 Dec. 2012 (International Maritime Bureau, 2013).

90. Okafor-Yarwood, I. The cyclical nature of maritime security threats: illegal, unreported and unregulated fishing as a threat to human and national security in the Gulf of Guinea. Afr. Secur. 31, 116-146 (2020).

91. Santos-Fita, D. Subsistence hunting in rural communities: incompatibilities and opportunities within Mexican environmental legislation. J. Ethnobiol. 38, 356-371 (2018).

92. Talma, J., Kotze, J. D., Markovina, M. \& Snijman, P. A Multi-Agency Task Team Working Together to End Destructive Blast Fishing. http://www.fao.org/fi/oldsite/eims_search/1 dett.asp?calling=simple s result\&lang=zh\&pub id=317379 (FAO \& IOC, 2015)

93. Galbraith, K. The horrors of fishing with dynamite. The New York Times (4 February 2015)

94. Ralby, I. \& Soud, D. Oil on the Water: Illicit Hydrocarbons Activity in the Maritime Domain (The Atlantic Council, 2018).

95. Banaseh, M. Ghana risks losing $\mathrm{GH} \$ 1.5 \mathrm{bn}$ to fuel smuggling. Graphic Online (23 August 2017)

96. Surtees, J. Venezuelan refugees feared drowned on route to Trinidad. The Guardian (25 April 2019).

97. Dambach, K. Human traffickers arrested in Italy. InfoMigrants (6 June 2019).

98. Frontex detects mother boat smuggling people. Frontex https://frontex.europa.eu/ media-centre/news-release/frontex-detects-mother-boat-smuggling-people-dIBt9Q (24 June 2019).

99. UNODC. Report of the meeting of the Working Group on the Smuggling of Migrants held in Vienna from 11 to 13 September 2019. CTOC/COP/WG.7/2019/6 (UN, 2019). This reports describes the use of fishing vessels to smuggle migrants by sea in the Mediterranean before 2016

100. Lindley, J., Percy, S. \& Techera, E. Illegal Fishing and Australian Security. http://www. internationalaffairs.org.au/australianoutlook/illegal-fishing-australia/ (Australian Insitute of International Affairs, 2018). 


\section{Perspective}

101. Lefevre, A. S. Thai fishermen convert boats to cash in on human-smuggling. Reuters https://www.reuters.com/article/us-thailand-rohingya/thai-fishermen-convert-boats-tocash-in-on-human-smuggling-idUSKCNOJ4OP120141120 (20 November 2015).

102. Spijkers, J. et al. Global patterns of fisheries conflict: forty years of data. Glob. Environ. Change 57, 101921 (2019).

103. Pomeroy, R. et al. Fish wars: conflict and collaboration in fisheries management in Southeast Asia. Mar. Policy 31 645-656 (2019).

104. Sumaila, U. R. \& Bawumia, M. Fisheries, ecosystem justice and piracy: a case study of Somalia. Fish. Res. 157, 154-163 (2019).

105. Chatham House. Maritime Security in the Gulf of Guinea (The Royal Institute of International Affairs, 2013).

106. Gilpin, R. Enhancing Maritime Security in the Gulf of Guinea. Strategic Studies Vol. VI (Center for Contemporary Conflict, 2007).

107. Onuoha, F. Piracy and Maritime Security in the Gulf of Guinea: Nigeria as a Microcosm (Al Jazeera Centre for Studies, 2012)

108. Okafor-Yarwood, I. The effects of oil pollution on the marine environment in the Gulf of Guinea-the Bonga Oil Field example. Transnatl Legal Theory 9, 254-271 (2018).

109. UN Security Council. Threats to International Peace and Security. Security Counci Resolution 2842/2019. 8582nd Meeting of the United Nations Security Council Report No. S/RES/2842 (UNSC, 2019)

110. UN. International Law of the Sea. Article 101 (UN, 1982).

111. UN Security Council. 7805th Meeting of the United Nations Security Council Report No. S/RES/2316 (UNSC, 2016).

112. Samatar, A. I., Lindberg, M. \& Mahayni, B. The dialectics of piracy in Somalia: the rich versus the poor. Third World Q. 31, 1377-1394 (2010)

113. Devlin, C., Glaser, S. M., Villegas, C. \& Poinsatte, N. Rough Seas: The Causes and Consequences of Fisheries Conflict in Somali Waters. https://securefisheries.org/ rough-seas-fisheries-conflict-somali-waters (One Earth Future, 2020).

114. Liss, C. The roots of piracy in Southeast Asia. APSNet Policy Forum (22 October 2007).

115. CCPCJ. Outcome of the 2nd International Symposium on Fisheries Crime, 10-11 October 2016, Yogyakarta, Indonesia. E/CN.15/2017/CRP.3 (UN ODC, 2017).

116. Tavornmas, A. From EU IUU yellow to green card: Thailand's sustainable fisheries, 2019. ASEAN Regional Forum (2019).

117. European Commission. EU Data Protection Rules. https://ec.europa.eu/commission/ priorities/justice-and-fundamental-rights/data-protection/2018-reform-eu-data-pro tection-rules/eu-data-protection-rules_en (2019)

118. Blowfield, M. \& Frynas, J. G. Setting new agendas: critical perspectives on corporate social responsibility in the developing world. Int. Aff. 81, 499-513 (2005)

119. Hodal, K., Kelly, C. \& Lawrence, F. Revealed: Asian slave labour producing prawns in supermarkets in US, UK. The Guardian (10 June 2014).

12O. Packer, H., Swarz, W., Ota, Y. \& Baily, M. Corporate social responsibility (CSR) practices of the largest seafood suppliers in the wild capture fisheries sector: from vision to action. Sustainability 11, 2254 (2019)

121. High Level Panel on a Sustainable Ocean Economy. Towards a Sustainable Ocean Economy Report. https://www.oceanpanel.org/the-report (2020).
Acknowledgements This manuscript is adapted from a Blue Paper commissioned by the High Level Panel for a Sustainable Ocean Economy entitled 'Organized Crime in the Fisheries Sector'. We thank T. Edmunds and D. G. Webster for their insightful input.

Author contributions E.W. is the first co-lead author; she was originally approached by the High Level Panel for a Sustainable Ocean Economy to lead the commissioned Blue Paper 16 on Organized Crime in the fisheries sector; she was tasked with the responsibility of appointing co-lead authors and contributing authors and the delivery of the final product. She wrote a substantial part of the text of the original draft framework paper, assigned writing roles and thereafter coordinated all input and led the reformulation of the paper. She further provided input on organized crime in fisheries in the South African context. E.W. drafted this Perspective with input from the co-lead authors. M.A.S. is a co-lead author. He provided substantial input for the draft framework paper, with specific reference to Indonesian examples, assisted in shaping the content of the paper, provided support throughout the writing process and contributed to the reformulation of the Blue paper and the Perspective. K.D.-A. is the third co-lead author. He provided substantial input for the draft framework paper, with specific reference to Gulf of Guinea examples and with particular input on maritime security concerns in the context of organized crime in the fisheries sector, assisted in shaping the content of the paper, provided support throughout the writing process and contributed to the reformulation of the Blue Paper and the Perspective. G.H. is a contributing author. She provided substantial input on sections concerning financial crime in the fisheries sector. Y.H. is a contributing author. He provided substantial input on sections concerning money laundering in the fisheries sector, specifically in the Indonesian context. S.M. is a contributing author. She provided substantial input on sections concerning organized crime in the fisheries sector in the Caribbean context. I.O.-Y. is a contributing author. She provided substantial input on sections concerning the impact of organized crime in the fisheries sector on coastal communities, particularly in the Nigerian context as well as in the broader Gulf of Guinea context. I.A.Q. is a contributing author. She provided substantial input on sections concerning the interface between environmental crime and organized crime in the fisheries sector in the Mexican context. O.S. is a contributing author. He provided substantial input on sections concerning organized crime in fisheries in the context of Colombia.

Competing interests The authors declare no competing interests.

Additional information

Supplementary information is available for this paper at https://doi.org/10.1038/s41586-020 2913-5.

Correspondence and requests for materials should be addressed to E.W.

Peer review information Nature thanks Timothy Edmunds and D. G. Webster for their contribution to the peer review of this work.

Reprints and permissions information is available at http://www.nature.com/reprints. Publisher's note Springer Nature remains neutral with regard to jurisdictional claims in published maps and institutional affiliations.

(c) Springer Nature Limited 2020 